This is the author's final, peer-reviewed manuscript as accepted for publication. The publisher-formatted version may be available through the publisher's web site or your institution's library.

\title{
Light intensity and wavelength influence development, reproduction and locomotor activity in the predatory flower bug Orius sauteri (Poppius) (Hemiptera: Anthocoridae)
}

S. Wang, X. L. Tan, J. P. Michaud, F. Zhang, X. Guo

\section{How to cite this manuscript}

If you make reference to this version of the manuscript, use the following information:

Wang, S., Tan, X. L., Michaud, J. P., Zhang, F., \& Guo, X. (2013). Light intensity and wavelength influence development, reproduction and locomotor activity in the predatory flower bug Orius sauteri (Poppius) (Hemiptera: Anthocoridae). Retrieved from http://krex.ksu.edu

\section{Published Version Information}

Citation: Wang, S., Tan, X. L., Michaud, J. P., Zhang, F., \& Guo, X. (2013). Light intensity and wavelength influence development, reproduction and locomotor activity in the predatory flower bug Orius sauteri (Poppius) (Hemiptera: Anthocoridae). BioControl, 58(5), 667-674.

Copyright: ( International Organization for Biological Control (IOBC) 2013

Digital Object Identifier (DOI): doi:10.1007/s10526-013-9522-2

Publisher's Link: http://link.springer.com/article/10.1007/s10526-013-9522-2

This item was retrieved from the K-State Research Exchange (K-REx), the institutional repository of Kansas State University. K-REx is available at http://krex.ksu.edu 


\title{
Light intensity and wavelength influence development, reproduction and locomotor activity in the predatory flower bug Orius sauteri (Poppius) (Hemiptera: Anthocoridae)
}

\author{
S. Wang ${ }^{1}$, X.L. Tan', J.P. Michaud ${ }^{3}$, F. Zhang ${ }^{1}$, X. Guo ${ }^{1}$ \\ ${ }^{1}$ Institute of Plant \& Environmental Protection, Beijing Academy of Agriculture \& \\ Forestry Sciences, Beijing 100097, China. \\ ${ }^{2}$ State Key Laboratory of Crop Stress Biology on the Arid Areas and Key Laboratory of \\ Crop Pest Management on the Losses Plateau of Ministry of Agriculture, Northwest \\ Agriculture \& Forestry University, Yangling, Shaanxi 712100, China. \\ ${ }^{3}$ Kansas State University, Department of Entomology, Agricultural Research Center- \\ Hays, 1232 240th Ave., Hays, KS, 67601, U.S.A. \\ *Correspondence:.jpmi@ksu.edu.
}

\begin{abstract}
Light wavelength and intensity are physical factors that can affect arthropod development and reproduction. The present study examined the development, reproduction and locomotor activity of the predatory flower bug, Orius sauteri (Poppius) (Hemiptera: Anthocoridae), under five light intensities (1000, 2000, 3000, 4000 and 5000 lux) and five wavelengths [red $(678.5 \mathrm{~nm})$, green $(620.0 \mathrm{~nm})$, yellow $(581.7 \mathrm{~nm})$, blue $(478.1 \mathrm{~nm})$ and white (all wavelengths)] at constant temperature $\left(25^{\circ} \mathrm{C}\right)$ and $\mathrm{RH}(70 \%)$. The duration of nymphal development was extended at lower light intensities, primarily due to effects on the first three instars. Under white, yellow and green light, O. sauteri completed development in $18.0 \mathrm{~d}$, but blue light extended development by $3.2 \mathrm{~d}$ and red light extended it by $7.4 \mathrm{~d}$. Although lower light intensities extended the preoviposition period and reduced fecundity, they improved egg fertility. Both red and blue light negatively affected preoviposition period, fecundity and egg fertility. Whereas adult female mean walking speed over a five min period was reduced at lower light intensities, longer wavelengths (yellow and red) increased it, ostensibly reflecting an avoidance response. The respiration quotient of adult $O$. sauteri females was also elevated under red light conditions. These findings are informative for optimizing $O$. sauteri massrearing procedures and maximizing its efficacy as a biological control agent in greenhouse cultures.
\end{abstract}


Keywords fecundity, fertility, locomotion, mating, oviposition, respiration quotient

\section{Introduction}

Various aspects of the photic environment, including photoperiod, intensity, wavelength and even polarization, may influence the development, metabolism and reproduction of arthropods. In particular, light intensity and wavelength are known to influence biological and physiological processes in insects (Bishop 1969; Manuwoto and Scriber 1985; Sakai et al. 2002). Predators and parasitoids have received substantial attention in this regard because of the need to understand photic influences on biological control outcomes (e.g., Omkar et al. 2005; Malaquias et al. 2010) and the suitability of lighting regimes for mass rearing natural enemies for augmentative biological control applications (Chambers 1977). For example, the aphid parasitoid Aphidius ervi Haliday (Hymenoptera: Aphidiinae) orients preferentially to green light as opposed to blue-green or yellow-green, ostensibly because of the association of aphid hosts with green foliage (Goff and Nault 1984). The predatory stonefly Eusthenia costalis Banks (Plecoptera: Eustheniidae) alters its foraging behaviour in response to small differences in wavelength between red and infrared light (Turnbull \& Barmuta 2006). Adults of Harmonia axyridis (Pallas) (Coleoptera: Coccinellidae) prefer to aggregate on white or highly reflective objects during flights to overwintering sites (Wang et al. 2011). Both photoperiod and light spectrum affect development and reproductive capacity in the aphidophagous coccinellid Coelophora saucia (Mulsant) (Coleoptera: Coccinellidae) (Omkar and Pathak 2006). Changes in light intensity have been linked to the induction and termination of diapause in various predatory Hemiptera and Coleoptera (Danks 1987). Diminishing light intensity eventually limits the ability of the bee Megalopta genalis Meade-Waldo (Hymenoptera: Halictidae) to find the nest entrance and thus determines the duration of crepuscular foraging behavior (Kelber et al. 2006). The whitefly parasitoids Encarsia formosa Gahan and Eretmocerus eremicus Rose and Zolnerowich (Hymenoptera: Aphelinidae) parasitized approximately twice as many hosts under conditions of high light intensity and long daylength as under low light intensity and short daylength (Zilahi-balogh et al. 2006). 
Flower bugs of the genus Orius (Wolff) (Hemiptera: Anthocoridae) are efficient predators of small insect pests, especially thrips, in many agroecosystems (Jacobson 1993; Pfannenstiel and Yeargan 1998; Lattin 1999). Previous work suggests that photic conditions affect many aspects of Orius spp. biology and behavior, including development, reproduction and orientation (Askari and Stern 1972; Smith and Stadelbacher 1978; Abenes and Khan 1990). For example, short daylength induces reproductive diapause in Orius strigicollis (Poppius) (Hemiptera: Anthocoridae), whereas long daylength tends to increase developmental duration, albeit with an interaction with temperature (Musolin et al. 2004). Similar results have been reported for O. insidiosus (Say) (Ruberson et al. 1991). Similarly, photoperiod was shown to influence survival, fecundity and longevity in O. thyestes Herring (Carvalho et al. 2006) and O. niger Wolff (Bahşi and Tunç 2008). Fewer studies have examined the effect of light intensity on the locomotor activity of Orius spp. or their distribution in habitats (Shields 1980; Gossner 2009), and studies of spectral effects (color) have not yet been conducted.

The present study examined the effects of different light intensities and wavelengths on development, reproduction and locomotor activity of the predatory flower bug Orius sauteri (Poppius) (Hemiptera: Anthocoridae). This beneficial species is mass-reared for augmentative release in vegetable greenhouses in Asia for suppression of arthropod pests such as thrips and aphids (Nakata 1995; Nagai and Yano 2000). Short daylength induces reproductive diapause in O. sauteri (Ito and Nakata 1998a; b) and photic conditions are known to influence other aspects of its development and reproduction in mass-reared cultures (Saulich and Musolin 2009). The primary objective of this study was generate better understanding of photic effects on aspects of $O$. sauteri developmental and reproductive biology and behavior that may affect either the efficacy of mass-rearing procedures or the insect's performance as a biological control agent following release in augmentation programs.

\section{Materials and Methods}

Insects 
A total of 390 O. sauteri adults (213 females and 177 males) were collected from alfalfa (Medicago sativa) fields around Wang Jia-Yuan Biodiversity Research Station (40 14 ' $\left.\mathrm{N}, 116^{\circ} 13^{\prime} \mathrm{E}\right)$ in Changping County, Beijing, China during the season of April to July, 2011. Species identity was confirmed by Dr. Cai Wanzhi, taxonomist of Hemiptera at Chinese Agricultural University, Beijing, China and these bugs were used to establish a colony in the Natural Enemy Research Laboratory at the Beijing Academy of Agriculture and Forestry Sciences, Haidian District, Beijing. Bugs were reared in aluminum frame cages $(45.0 \times 50.0 \times 60.0 \mathrm{~cm})$ covered with fabric net $(100 \mathrm{mesh})$, beginning with 30 bugs/cage, in a climate-controlled growth chamber (MH-351, Sanyo, Japan) set to $25 \pm$ $1^{\circ} \mathrm{C}, 70 \pm 2 \% \mathrm{RH}, 16: 8 \mathrm{~L}: \mathrm{D}$ photoperiod, 3000 lux fluorescent light. The cowpea aphid, Aphis craccivora Koch (Hemiptera: Aphididae), reared on broad bean, Vicia faba L., was provided as food and kidney bean plants, Phaseolus vulgaris L., as an oviposition substrate (Murai et al. 2001). The stock colony was managed as a continuous culture. New plants were introduced every four days and heavily damaged plants removed, their stems clipped and left in cages until bugs eclosed.

Luminosity and wavelength treatments

Experiments were conducted in climate-controlled growth chambers under the same physical conditions as above, unless otherwise specified. For the luminosity treatments, white fluorescent lights were set to one of five light intensities (1000, 2000, 3000, 4000 or 5000 lux). For wavelength treatments, colored LED lamps (LENSER-IllumineTM, Shenzhen, China) were used in place of the stock fluorescent lamps and luminosity was set at 3000 lux in all treatments. The following wavelength treatments were established: $678.5 \mathrm{~nm}$ (red), $620.0 \mathrm{~nm}$ (yellow), $581.7 \mathrm{~nm}$ (green), $478.1 \mathrm{~nm}$ (blue) and fluorescent white (control). Actual wavelengths were measured to an accuracy of $\pm 10-15 \mathrm{~nm}$ using an LED analyzer (Feasa Enterprises limited, Limerick, Ireland). A thermal probe was used to verify that temperatures experienced by the insects in various containers remained at $25 \pm 1{ }^{\circ} \mathrm{C}$ across all lighting treatments.

Development assay 
Bugs for experiments were obtained by placing kidney bean stems bearing freshly laid eggs of $O$. sauteri ( $24 \pm 2 \mathrm{~h}$ old post-moulting) in clean plastic Petri dishes $(10.0 \mathrm{~cm}$ diameter), three per dish. As nymphs hatched, they were transferred to smaller Petri dishes ( $4.5 \mathrm{~cm}$ diameter, 1 bug per dish) within one h of eclosion. Each dish was provisioned with ca. 40 3rd instar aphids (replaced every $24 \mathrm{~h}$ without removing containers from growth chambers) and covered with perforated Parafilm ${ }^{\circledR}$. Nymphs in experiments were examined every four $h$, using an infrared camera to make night-time observations, the developmental status of each was recorded, and the proportion surviving to the adult stage was tallied. A total of 25 replicates were conducted simultaneusly at each light intensity and wavelength treatment.

\section{Reproduction assay}

Virgin O. sauteri adults ( $24 \pm 2 \mathrm{~h}$ old $)$ were paired in plastic Petri dishes (10.0 cm diam) with abundant food ( $>60$ aphids, replaced daily) and assigned to one of the five light intensity or wavelength treatments. Pairs were observed continuously from onset of copulation (maintenance of genital contact for $\geq 5 \mathrm{~min}$ ) until male and female separated and then every four $\mathrm{h}$ thereafter. Males were then removed and each female provided five $P$. vulgaris stems as oviposition substrates. The duration of copula and preoviposition period were determined by direct observation. Bean stems were replaced daily and held under the same physical conditions until eclosion of neonate bugs; fecundity and egg fertility was followed for five days by examining all oviposition punctures and dividing the number of bugs eclosing by the total number of hatched and unhatched eggs. The test was repeated five times with five pairs in each light intensity for a total of 25 replicates per treatment.

\section{Respiration assay}

We reasoned that changes in the respiratory quotient should be evident if light conditions affect $O$. sauteri metabolic rate. A respirometry system (Sable Systems International, 
Las Vegas, NV, USA) was used to measure the respiratory quotient of individual newly molted adult female bugs ( $24 \pm 2 \mathrm{~h}$ old) under the various conditions of luminosity and wavelength described above. The apparatus consisted of a $\mathrm{CO}_{2}$ infrared analyzer (Testo 535, Testo, Lenzkirch, Germany), an $\mathrm{O}_{2}$ gas sensor (InPro 6000G, Mettler-Toledo, Greifensee, Switzerland), an air pump, a flow meter, a $\mathrm{CO}_{2}$ purification tube, a drying tube, a glass sample chamber $(2.0 \mathrm{~cm}$ ID $\times 10.0 \mathrm{~cm})$, a data collector (Vernier LabPro, Beaverton, OR, USA) and a temperature sensor (TMP-112, Texas Instruments, Dallas, TX, USA). The apparatus was assembled within an aluminum box $(65.0 \times 40.0 \times 40.0$ $\mathrm{cm}$ ) with light sources mounted on the inside and temperature was maintained at $25 \pm$ $1^{\circ} \mathrm{C}$. Air flow was adjusted to $0.1 \mathrm{~L} / \mathrm{min}$ in the apparatus and initial $\mathrm{O}_{2}$ and $\mathrm{CO}_{2}$ concentrations were recorded. Once all readings were stable, insects $(n=10$ adult females per treatment) were placed singly in the sample chamber and measurements made on each for a period of $30 \mathrm{~min}$. The respiratory quotient (RQ) was calculated according to manufacturer's specifications as:

$$
\mathrm{RQ}=\left(\% \mathrm{CO}_{2} \text { expired }-\% \mathrm{CO}_{2} \text { inspired }\right) /\left(\% \mathrm{O}_{2} \text { inspired }-\% \mathrm{O}_{2} \text { expired }\right)
$$

\section{Locomotion assay}

A tracksphere locomotion compensator with behavior recorder (Syntech LC-100, Hilversum, Netherlands) was used to monitor differences in locomotor activity under various light intensities and wavelengths. After adjustment of focus, the device was covered with tin foil shade to exclude ambient light and four white LED lamps were placed in the shade. Light intensity was regulated by an auto regulator (light intensity measurer, TPM-Z1, Leaderlab ${ }^{\circledR}$, Hangzhou, China). Newly emerged O. sauteri females were placed singly on top of the monitoring sphere. The sphere adjusted its speed to maintain the insect on the top and the bug's movement was recorded continuously for five min. The behavior recorder sums all movements of the sphere to yield an estimate of linear distance that is then divided by the time of the observation to yield a walking speed. A total of 10 females were observed under each light intensity treatment, and 35 under each wavelength treatment. 
Statistical analysis

Data from all experiments were analyzed by one-way ANOVA (SPSS 1998) and means separated by $\operatorname{LSD}(\alpha=0.05)$.

\section{Results}

The total duration of $O$. sauteri development decreased with increasing light intensity, largely due to faster development in the first, second and third nymphal instars, the fourth and fifth instars remaining largely unaffected (Table 1). Nymphal development was fastest under white, green and yellow light, slower under blue light, and very slow under red light, with significant effects of wavelength on the durations of all nymphal instars (Table 2).

There were significant effects of light intensity on all reproductive parameters. Duration of copula and preoviposition period were both decreased by increasing light intensity, but fecundity was maximal at intermediate light intensity and egg fertility was maximal at low intensity (Table 3 ). White, green and yellow light yielded the longest durations of copula, shortest preoviposition periods, and the highest levels of fecundity and egg fertility (Table 4). Light intensity did not significantly affect the respiration quotient $\left(F_{4,45}=1.86, P=0.133\right)$ but wavelength did $\left(F_{4,45}=2.97, P=0.029\right)$. Bugs under red light exhibited a significantly higher RQ value than did those under other wavelength treatments, none of which differed significantly (Fig. 1).

The walking speed of $O$. sauteri females averaged over five one-minute intervals increased almost two-fold as light intensity was increased from 1000 to 5000 lux (Table 5). Vagility was highest under red light conditions, intermediate under yellow, and lowest under white, green and blue (Table 6).

\section{Discussion}


Although $O$. sauteri was able to develop and reproduce successfully under the full range of photic conditions tested, both light intensity and wavelength exerted significant influences on its biology and behavior. Early instar nymphs of $O$. sauteri were particularly sensitive to light intensity and their development was delayed below 4000 lux, suggesting a diurnal species adapted to development in brightly lit habitats. The delayed development observed under red and blue light is perhaps suggestive of adaptation to development under light in the yellow-green range, consistent with what would be expected in a natural plant canopy. The equivalent suitability of white light to that of yellow and green suggests that it is not so much the perception of wavelengths longer or shorter than yellow-green that delays development, but rather the absence of wavelengths within this optimal range. Nevertheless, previous studies have demonstrated negative effects of short wavelength light on mating behaviour in Drosophila melanogaster (Jacobs 1960; Sakai et al. 2002) and on feeding behaviour in both Diptera (Lunau and Wacht 1997), and Lepidoptera (White et al. 1994), whereas red light has been shown to impede development in coccinellids (Omkar et al. 2005).

Since developmental rate was almost $20 \%$ faster at the highest light intensity compared to the lowest, cultures of $O$. sauteri should employ light intensity higher than 4000 lux if the objective is to speed the production of large numbers. Likewise, adult locomotor activity increased with light intensity (Table 5), which might translate into a beneficial effect on foraging behaviour under supplementary lighting in a greenhouse environment. White light was generally most suitable for reproduction, although not significantly superior to yellow or green (Table 4). However, bugs reproducing under red light took longer to lay eggs and had reduced fecundity and fertility. Thus, the greater walking speed of adult females under red light (Table 6) likely reflects an avoidance response to this wavelength of light, an inference that would be consistent with the higher observed RQ (Fig. 1). This might result in lower rates of prey consumption and thus account for the negative effect on reproduction. Both red and blue light were shown to cause erratic reproductive activity in two species of Coccinellidae (Omkar et al. 2005). Notably, Castrejon and Rojas (2010) found differences between larvae and mated female adults of Estigmene acrea (Drury) (Lepidoptera: Arctiidae) in selective orientation to different wavelengths of light, the former preferring green, the color of food plants, and 
the latter wavelengths in the range of blue to UV, ostensibly useful as cues for orienting to oviposition sites.

Light intensity had inconsistent effects on different parameters of $O$. sauteri reproduction (Table 3). Notably, Nissenen et al. (2008) found that gravid and virgin female carrot psyllids, Trioza apicalis Forster (Hemiptera: Triozidae), responded differently to subtle differences in light intensity. Higher luminosities shortened the duration of copula for $O$. sauteri, accelerated the onset of oviposition, and yielded higher fecundities, but significantly reduced fertility, possibly due in part to the effect on mating time. Thus, the high light intensities that favor rapid bug development and reproduction are associated with reductions in egg fertility. One possible application of this finding in commercial production of $O$. sauteri might be the regular harvest of egg-bearing plant parts so that these can be held under lower light conditions until emergence of nymphs. Alternatively, the cage environment could be modified so that oviposition sites are shaded and experience lower light intensity than the rest of the enclosure. Further experiments could test whether females respond to differences in light intensity when selecting oviposition sites.

\section{References}

Abenes M, Khan Z (1990) Attractiveness of light color to selected predators of rice pests. International Rice Research Newsletter 15:24-25

Askari A, Stern V (1972) Effect of temperature and photoperiod on Orius tristicolor feeding on Tetranychus pacificus. J Econ Entomol 65:132-135

Bahşi Ş, Tunç İ (2008) Development, survival and reproduction of Orius niger (Hemiptera:Anthocoridae) under different photoperiod and temperature regimes. BioControl Sci Technol 18:767-778

Bishop J (1969) Light control of aquatic insect activity and drift. Ecology 50: 371-380

Carvalho AR, Bueno VHP, Pedroso EC, Kon LI, Diniz AJF, Silva RJ (2006) Influence of photoperiod on Orius thyestes Herring (Hemiptera: Anthocoridae) reproduction and longevity. Neotrop Entomol 35:489-492

Castrejon F, Rojas JC (2010) Behavioral responses of larvae and adults of Estigmene acrea (Lepidoptera: Arctiidae) to light of different wavelengths. Fla Entomol 93:505-509

Chambers D (1977) Quality control in mass rearing. Annu Rev Entomol 22:289-308.

Danks H (1987) Insect Dormancy: An Ecological Perspective. Biological Survey of Canada Monograph Series 1, Ottawa, Canada, 439 pp 
Goff A, Nault L (1984) Response of the pea aphid parasite Aphidius ervi Haliday (Hymenoptera: Aphidiidae) to transmitted light. Environ Entomol 13:595-598

Gossner M (2009) Light intensity affects spatial distribution of Heteroptera in deciduous forests. Eur J Entomol 106:241-252

Ito K, Nakata T (1998a) Diapause and survival in winter in two species of predatory bugs, Orius sauteri and O. minutus. Entomol Exp Appl. 89:271-276

Ito K, Nakata T (1998b) Effect of photoperiod on reproductive diapause in the predatory bugs, Orius sauteri (Poppius) and O. minutus (Linnaeus) (Heteroptera : Anthocoridae). Appl. Entomol Zool $33: 115-120$

Jacobs M (1960) Influence of light on mating of Drosophila melanogaster. Ecology 41:182-188

Jacobson R (1993) Control of Frankiniella occidentalis with Orius majusculus: experiences during the first full season of commercial use in the U.K. IOBC/WPRS Bull 16:81-84

Kelber A, Warrant E, Pfaff M, Wallén R, Theobald J, Wcislo W, Raguso R (2006) Light intensity limits foraging activity in nocturnal and crepuscular bees. Behav Ecol 17:63-72

Lattin J (1999) Bionomics of the Anthocoridae. Annu Rev Entomol 44:207-231

Lunau K., Wacht S. (1997) Innate flower recognition in the hoverfly Eristalis tenax L. Mitteil Deutsch Gesellsch Allgem Angew Entomol 11:481-484

Malaquias J, Ramalho F, Fernandes F, Nascimento Júnior J, Correia E, Zanuncio J (2010) Effects of photoperiod on reproduction and longevity of Podisus nigrispinus (Heteroptera: Pentatomidae). Ann Entomol Soc Am 103:603-610

Manuwoto S, Scriber J (1985) Neonate larval survival of European corn borers, Ostrinia nubilalis, on high and low dimboa genotypes of maize: Effects of light intensity and degree of insect inbreeding. Agric Ecosys Environ 14:3-4

Murai T, Narai Y, Sugiura N (2001) Utilization of germinated broad bean seeds as an oviposition substrate in mass rearing of the predatory bug, Orius sauteri (Poppius) (Heteroptera: Anthocoridae). Appl Entomol Zool 36:489-495

Musolin D, Tsytsulina K, Ito K (2004) Photoperiodic and temperature control of reproductive diapause induction in the predatory bug Orius strigicollis (Heteroptera: Anthocoridae) and its implications for biological control. Biol Control 31:91-98

Nagai K, Yano E (2000) Predation by Orius sauteri (Poppius) (Heteroptera: Anthocoridae) on Thrips palmi Karny (Thysanoptera: Thripidae): Functional response and selective predation. Appl Entomol Zool 35:565-574

Nakata T (1995) Population fluctuations of aphids and their natural enemies on potato in Hokkaido, Japan. Appl Entomol Zool 30:129-138

Nissenan A, Kristoffersen L, Anderbrant O (2008) Physiological state of female and light intensity affect the host-plant selection of carrot psyllid, Trioza apicalis (Hemiptera: Triozidae). Eur J Entomol $105: 227-232$ 
Omkar, Mishra G, Singh K (2005) Effects of different wavelengths of light on the life attributes of two aphidophagous ladybirds (Coleoptera: Coccinellidae). Eur J Entomol 102:33-37

Omkar, Pathak S (2006) Effects of different photoperiods and wavelengths of light on the life-history traits of an aphidophagous ladybird, Coelophora saucia (Mulsant). J Appl Entomol 130:45-50

Pfannenstiel RS, Yeargan (1998) Association of predatory Hemiptera with selected crops. Environ Entomol 27:232-239

Ruberson J, Bush L, Kring T (1991) Photoperiodic effect on diapause induction and development in the predator Orius insidiosus (Heteroptera: Anthocoridae). Environ Entomol 20:786-789

Sakai T, Isono K, Tomaru M, Fukatami A, Oguma Y (2002) Light wavelength dependency of mating activity in the Drosophila melanogaster species subgroup. Genes Gen Sys 77:187-195

Saulich AK, Musolin DL (2009) Seasonal development and ecology of anthocorids (Heteroptera, Anthocoridae). Entomol Rev 89:501-528

Shields EJ (1980) Locomotory activity of Orius tristicolor under various intensities of flickering and nonflickering light. Ann Entomol Soc Am 73:74-77

Smith JW, Stadelbacher EA (1978) Predatory arthropods: seasonal rise and decline of populations in cotton fields in the Mississippi delta. Environ Entomol 7:367-371

SPSS (1998) SPSS 8.0 for windows. SPSS Inc. Prentice Hall, New Jersey

Turnbull DKR, Barmuta LA (2006) Different light conditions influence the activity of Eusthenia costalis Banks (Plecoptera: Eustheniidae). Int J Freshw Entomol 28:211-217

Wang S, Michaud JP, Tan XL, Zhang F, Guo XJ (2011) The aggregation behavior of Harmonia axyridis in its native range in Northeast China. BioControl 56:193-206

White RH, Stevenson RD, Bennett RR, Culter DE (1994) Wavelength discrimination and the role of ultraviolet vision in the feeding behavior of hawkmoths. Biotropica 26:427-435

Zilahi-balogh GM, Shipp JL, Cloutier C, Brodeur J. (2006) Influence of light intensity, photoperiod, and temperature on the efficacy of two aphelinid parasitoids of the greenhouse whitefly. Environ Entomol 35:581-589 
Table 1. Mean duration ( $d \pm S E$ ) of various $O$. sauteri nymphal stages $(n=5$ replicates of 5 bugs each per treatment) when reared at $25 \pm 1{ }^{\circ} \mathrm{C}$ under five different intensities of white fluorescent light. Values bearing the same letter were not significantly different within columns (LSD test, $\alpha=0.05$ )

\begin{tabular}{lllllll}
\hline \multirow{2}{*}{ Light intensity (lux) } & \multicolumn{5}{c}{ Nymphal instar } & \multirow{2}{*}{ Total } \\
\cline { 2 - 5 } & \multicolumn{1}{c}{ First } & \multicolumn{1}{c}{ Second } & \multicolumn{1}{c}{ Third } & Fourth & Fifth & \\
\hline 1000 & $4.3 \pm 0.2 \mathrm{a}$ & $3.7 \pm 0.2 \mathrm{a}$ & $3.5 \pm 0.1 \mathrm{a}$ & $4.1 \pm 0.3 \mathrm{a}$ & $4.2 \pm 0.3 \mathrm{a}$ & $19.7 \pm 0.5 \mathrm{a}$ \\
2000 & $3.9 \pm 0.2 \mathrm{ab}$ & $3.3 \pm 0.2 \mathrm{ab}$ & $3.3 \pm 0.2 \mathrm{a}$ & $3.8 \pm 0.2 \mathrm{a}$ & $4.1 \pm 0.2 \mathrm{a}$ & $18.3 \pm 0.4 \mathrm{~b}$ \\
3000 & $3.8 \pm 0.1 \mathrm{~b}$ & $3.2 \pm 0.1 \mathrm{~b}$ & $3.0 \pm 0.2 \mathrm{a}$ & $3.8 \pm 0.1 \mathrm{a}$ & $4.0 \pm 0.3 \mathrm{a}$ & $17.8 \pm 0.3 \mathrm{~b}$ \\
4000 & $3.1 \pm 0.1 \mathrm{c}$ & $2.8 \pm 0.1 \mathrm{c}$ & $2.4 \pm 0.1 \mathrm{~b}$ & $3.9 \pm 0.2 \mathrm{a}$ & $4.2 \pm 0.1 \mathrm{a}$ & $16.5 \pm 0.2 \mathrm{c}$ \\
5000 & $2.9 \pm 0.1 \mathrm{c}$ & $2.6 \pm 0.2 \mathrm{c}$ & $2.3 \pm 0.1 \mathrm{~b}$ & $4.1 \pm 0.1 \mathrm{a}$ & $4.2 \pm 0.1 \mathrm{a}$ & $16.2 \pm 0.3 \mathrm{c}$ \\
$F$ & 19.794 & 15.557 & 16.875 & 0.940 & 0.555 & 13.446 \\
$\mathrm{df}$ & 4,120 & 4,120 & 4,120 & 4,120 & 4,120 & 4,120 \\
$P$ & $<0.001$ & $<0.001$ & $<0.001$ & 0.443 & 0.696 & $<0.001$ \\
\hline
\end{tabular}

Table 2. Mean duration ( $\mathrm{d} \pm \mathrm{SE}$ ) of various $O$. sauteri nymphal stages ( $\mathrm{n}=5$ replicates of 5 bugs each per treatment) when reared at $25 \pm 1{ }^{\circ} \mathrm{C}$ under five different wavelengths of light at 3000 lux. Values bearing the same letter were not significantly different within columns (LSD test, $\alpha=0.05$ )

\begin{tabular}{lllllll}
\hline & \multicolumn{5}{c}{ Nymphal instar } & \multirow{2}{*}{ Total } \\
\cline { 2 - 6 } Wavelength (nm) & \multicolumn{1}{c}{ First } & \multicolumn{1}{c}{ Second } & \multicolumn{1}{c}{ Third } & \multicolumn{1}{c}{ Fourth } & Fifth & T. \\
\hline Red (678.5) & $5.9 \pm 0.1 \mathrm{a}$ & $5.1 \pm 0.2 \mathrm{a}$ & $4.7 \pm 0.2 \mathrm{a}$ & $4.7 \pm 0.1 \mathrm{a}$ & $5.1 \pm 0.1 \mathrm{a}$ & $25.4 \pm 0.4 \mathrm{a}$ \\
Yellow (620.0) & $4.1 \pm 0.1 \mathrm{c}$ & $3.1 \pm 0.1 \mathrm{c}$ & $3.3 \pm 0.1 \mathrm{c}$ & $3.6 \pm 0.1 \mathrm{bc}$ & $4.0 \pm 0.1 \mathrm{~b}$ & $18.0 \pm 0.3 \mathrm{c}$ \\
Green (581.7) & $3.9 \pm 0.1 \mathrm{c}$ & $3.2 \pm 0.2 \mathrm{c}$ & $3.2 \pm 0.3 \mathrm{c}$ & $3.5 \pm 0.2 \mathrm{c}$ & $4.2 \pm 0.1 \mathrm{~b}$ & $18.0 \pm 0.3 \mathrm{c}$ \\
Blue (478.1) & $5.2 \pm 0.1 \mathrm{~b}$ & $4.1 \pm 0.1 \mathrm{~b}$ & $3.6 \pm 0.1 \mathrm{~b}$ & $3.9 \pm 0.2 \mathrm{~b}$ & $4.5 \pm 0.2 \mathrm{~b}$ & $21.2 \pm 0.5 \mathrm{~b}$ \\
White & $3.9 \pm 0.1 \mathrm{c}$ & $3.2 \pm 0.2 \mathrm{c}$ & $3.3 \pm 0.1 \mathrm{c}$ & $3.5 \pm 0.1 \mathrm{c}$ & $4.1 \pm 0.2 \mathrm{~b}$ & $18.0 \pm 0.2 \mathrm{c}$ \\
$F$ & 75.242 & 70.372 & 37.664 & 30.130 & 13.257 & 223.605 \\
df & 4,120 & 4,120 & 4,120 & 4,120 & 4,120 & 4,120 \\
$P$ & $<0.001$ & $<0.001$ & $<0.001$ & $<0.001$ & $<0.001$ & $<0.001$ \\
\hline
\end{tabular}


Table 3. Mean reproductive parameters $( \pm \mathrm{SE})$ for $O$. sauteri adult pairs $(\mathrm{n}=5$ replicates of 5 pairs per treatment) when reared at $25 \pm 1{ }^{\circ} \mathrm{C}$ under five different intensities of white fluorescent light. Values bearing the same letter were not significantly different within columns (LSD test, $\alpha=0.05$ )

\begin{tabular}{lcccc}
\hline \hline & \multicolumn{4}{c}{ Parameter } \\
\cline { 2 - 5 } Light intensity (lux) & $\begin{array}{c}\text { Duration of } \\
\text { copula (min) }\end{array}$ & $\begin{array}{c}\text { Preoviposition } \\
\text { period (d) }\end{array}$ & $\begin{array}{c}\text { 5-day fecundity } \\
\text { (no. eggs) }\end{array}$ & $\begin{array}{c}\text { Fertility (\% eggs } \\
\text { hatching) }\end{array}$ \\
\hline 1000 & $11.6 \pm 0.4 \mathrm{a}$ & $11.2 \pm 0.4 \mathrm{a}$ & $30.2 \pm 1.4 \mathrm{~b}$ & $92.7 \pm 2.0 \mathrm{a}$ \\
2000 & $10.4 \pm 0.3 \mathrm{a}$ & $11.1 \pm 0.6 \mathrm{ab}$ & $34.1 \pm 1.8 \mathrm{~b}$ & $85.3 \pm 3.2 \mathrm{~b}$ \\
3000 & $7.6 \pm 0.4 \mathrm{~b}$ & $9.8 \pm 0.3 \mathrm{~b}$ & $40.3 \pm 2.1 \mathrm{a}$ & $73.8 \pm 2.1 \mathrm{c}$ \\
4000 & $6.1 \pm 0.4 \mathrm{c}$ & $8.4 \pm 0.4 \mathrm{c}$ & $39.1 \pm 1.9 \mathrm{a}$ & $61.7 \pm 4.0 \mathrm{~d}$ \\
5000 & $5.9 \pm 0.3 \mathrm{c}$ & $7.7 \pm 0.8 \mathrm{c}$ & $39.3 \pm 1.1 \mathrm{a}$ & $54.2 \pm 2.5 \mathrm{e}$ \\
$F$ & 66.848 & 18.210 & 13.725 & 91.977 \\
df & 4,120 & 4,120 & 4,120 & 4,120 \\
$P$ & $<0.001$ & $<0.001$ & $<0.001$ & $<0.001$ \\
\hline
\end{tabular}

Table 4. Mean reproductive parameters $( \pm \mathrm{SE})$ for $O$. sauteri adult pairs $(n=5$ replicates of 5 bugs per treatment) when reared at $25 \pm 1{ }^{\circ} \mathrm{C}$ under five different wavelengths of light at 3000 lux. Values bearing the same letter were not significantly different within columns (LSD test, $\alpha$ $=0.05)$

\begin{tabular}{llccl}
\hline \hline & \multicolumn{4}{c}{ Variable } \\
\cline { 2 - 5 } Wavelength (nm) & $\begin{array}{c}\text { Duration of } \\
\text { copula (min) }\end{array}$ & $\begin{array}{c}\text { Preoviposition } \\
\text { period (d) }\end{array}$ & $\begin{array}{c}5 \text {-day fecundity } \\
\text { (no. eggs) }\end{array}$ & $\begin{array}{c}\text { Fertility (\% } \\
\text { eggs hatching) }\end{array}$ \\
\hline Red (678.5) & $6.2 \pm 0.3 \mathrm{~b}$ & $14.9 \pm 1.1 \mathrm{a}$ & $37.2 \pm 2.3 \mathrm{~b}$ & $59.1 \pm 2.6 \mathrm{~b}$ \\
Yellow (620.0) & $7.8 \pm 0.4 \mathrm{ab}$ & $10.6 \pm 0.6 \mathrm{bc}$ & $42.5 \pm 1.3 \mathrm{a}$ & $72.7 \pm 2.5 \mathrm{a}$ \\
Green (581.7) & $8.2 \pm 0.5 \mathrm{a}$ & $9.9 \pm 0.5 \mathrm{c}$ & $43.1 \pm 1.4 \mathrm{a}$ & $74.1 \pm 2.4 \mathrm{a}$ \\
Blue (478.1) & $6.9 \pm 0.2 \mathrm{~b}$ & $12.4 \pm 0.6 \mathrm{~b}$ & $33.3 \pm 1.7 \mathrm{~b}$ & $63.6 \pm 3.6 \mathrm{~b}$ \\
White & $7.4 \pm 0.2 \mathrm{ab}$ & $9.5 \pm 0.3 \mathrm{c}$ & $41.8 \pm 1.8 \mathrm{a}$ & $74.5 \pm 2.8 \mathrm{a}$ \\
$F$ & 12.687 & 25.893 & 13.536 & 14.718 \\
df & 4,120 & 4,120 & 4,120 & 4,120 \\
$P$ & $<0.001$ & $<0.001$ & $<0.001$ & $<0.001$ \\
\hline
\end{tabular}


Table 5. Mean walking speed $(\mathrm{mm} / \mathrm{sec} \pm \mathrm{SE})$ of $O$. sauteri female adults $(\mathrm{n}=10$ per treatment) in one-minute intervals under five different intensities of white fluorescent light. Values bearing the same letter were not significantly different within columns (LSD test, $\alpha=0.05$ )

\begin{tabular}{lcccccc}
\hline & \multicolumn{5}{c}{ Time interval } & \\
\cline { 2 - 6 } Light intensity (lux) & First & Second & Third & Fourth & Fifth & Average \\
\hline 1000 & $8.8 \pm 0.7 \mathrm{~b}$ & $8.6 \pm 0.9 \mathrm{~b}$ & $7.1 \pm 0.9 \mathrm{~b}$ & $5.7 \pm 0.6 \mathrm{~d}$ & $5.4 \pm 1.1 \mathrm{~d}$ & $7.1 \pm 0.4 \mathrm{~d}$ \\
2000 & $9.0 \pm 1.4 \mathrm{~b}$ & $8.9 \pm 0.8 \mathrm{~b}$ & $7.7 \pm 0.5 \mathrm{~b}$ & $7.4 \pm 0.3 \mathrm{c}$ & $7.1 \pm 0.2 \mathrm{c}$ & $8.0 \pm 0.4 \mathrm{~cd}$ \\
3000 & $9.2 \pm 0.7 \mathrm{~b}$ & $8.9 \pm 0.6 \mathrm{~b}$ & $8.2 \pm 0.5 \mathrm{~b}$ & $8.0 \pm 0.6 \mathrm{c}$ & $7.8 \pm 0.9 \mathrm{c}$ & $8.4 \pm 0.3 \mathrm{c}$ \\
4000 & $12.6 \pm 1.3 \mathrm{a}$ & $11.2 \pm 0.9 \mathrm{ab}$ & $10.5 \pm 0.7 \mathrm{ab}$ & $10.2 \pm 0.5 \mathrm{~b}$ & $9.9 \pm 0.7 \mathrm{~b}$ & $10.9 \pm 0.4 \mathrm{~b}$ \\
5000 & $13.1 \pm 0.9 \mathrm{a}$ & $13.1 \pm 1.0 \mathrm{a}$ & $12.2 \pm 1.4 \mathrm{a}$ & $12.3 \pm 0.7 \mathrm{a}$ & $12.4 \pm 1.2 \mathrm{a}$ & $12.6 \pm 0.5 \mathrm{a}$ \\
$F$ & 4.12 & 5.10 & 6.03 & 20.52 & 9.71 & 34.03 \\
$\mathrm{df}$ & 4,45 & 4,45 & 4,45 & 4,45 & 4,45 & 4,45 \\
$P$ & 0.006 & 0.002 & 0.001 & $<0.001$ & $<0.001$ & $<0.001$ \\
\hline
\end{tabular}

Table 6. Mean walking speed ( $\mathrm{mm} / \mathrm{sec} \pm \mathrm{SE})$ of $O$. sauteri female adults $(\mathrm{n}=35$ per treatment) during one-minute intervals under five different wavelengths of light. Values bearing the same letter were not significantly different within columns (LSD test, $\alpha=$ $0.05)$

\begin{tabular}{lcccccc}
\hline & \multicolumn{5}{c}{ Time interval } & \multirow{2}{*}{ Average } \\
\cline { 2 - 6 } Wavelength (nm) & First & Second & Third & Fourth & Fifth & A.10.3 \\
\cline { 2 - 6 } Red (678.5) & $13.2 \pm 0.7 \mathrm{a}$ & $11.1 \pm 0.5 \mathrm{a}$ & $10.1 \pm 0.7 \mathrm{a}$ & $9.4 \pm 0.2 \mathrm{a}$ & $7.8 \pm 0.3 \mathrm{a}$ & $10.8 \mathrm{a}$ \\
Yellow (620.0) & $11.7 \pm 0.7 \mathrm{a}$ & $9.7 \pm 0.3 \mathrm{~b}$ & $9.2 \pm 0.4 \mathrm{a}$ & $9.1 \pm 0.8 \mathrm{a}$ & $7.4 \pm 0.8 \mathrm{a}$ & $9.4 \pm 0.8 \mathrm{~b}$ \\
Green (581.7) & $9.6 \pm 0.7 \mathrm{~b}$ & $9.3 \pm 0.5 \mathrm{bc}$ & $8.2 \pm 0.3 \mathrm{~b}$ & $7.4 \pm 0.5 \mathrm{~b}$ & $6.7 \pm 0.4 \mathrm{a}$ & $8.2 \pm 0.6 \mathrm{c}$ \\
Blue (478.1) & $8.3 \pm 0.7 \mathrm{~b}$ & $8.3 \pm 0.5 \mathrm{c}$ & $8.2 \pm 0.4 \mathrm{~b}$ & $7.3 \pm 0.7 \mathrm{~b}$ & $6.4 \pm 0.5 \mathrm{a}$ & $7.7 \pm 0.9 \mathrm{c}$ \\
White & $9.2 \pm 0.4 \mathrm{~b}$ & $9.0 \pm 0.6 \mathrm{bc}$ & $8.1 \pm 0.4 \mathrm{~b}$ & $7.6 \pm 0.2 \mathrm{~b}$ & $7.0 \pm 0.3 \mathrm{a}$ & $8.2 \pm 0.6 \mathrm{c}$ \\
$F$ & 12.69 & 6.52 & 7.10 & 5.75 & 0.68 & 15.18 \\
df & 4,45 & 4,45 & 4,45 & 4,45 & 4,45 & 4,45 \\
$P$ & $<0.001$ & $<0.001$ & $<0.001$ & $<0.001$ & 0.608 & $<0.001$ \\
\hline
\end{tabular}


Fig. 1

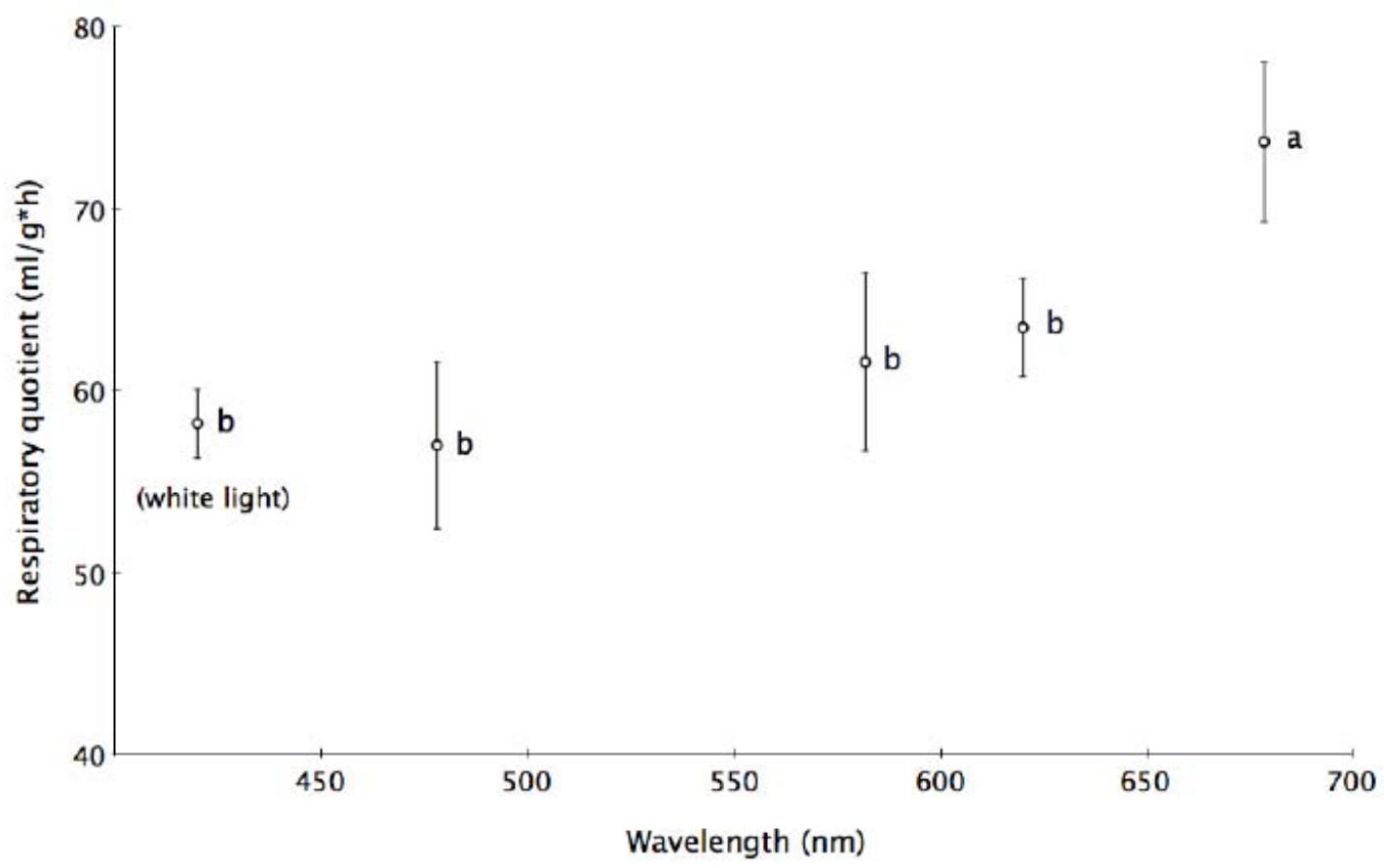

Fig. 1. Mean $( \pm \mathrm{SE})$ respiration quotients of adult female $O$. sauteri measured under different wavelengths of light. Data points bearing the same letters were not significantly different (LSD test, $\alpha=0.05$ ). 